\title{
The ethical and spiritual considerations of Matthew's Beatitudes: Configuration of the human being in companies
}

\begin{tabular}{|c|c|}
\hline \multicolumn{2}{|c|}{$\begin{array}{l}\text { Authors: } \\
\text { Carolina Vila Porras }{ }^{1} \text { (D) } \\
\text { Iván D. Toro-Jaramillo }\end{array}$} \\
\hline \multicolumn{2}{|c|}{$\begin{array}{l}\text { Affiliations: } \\
\text { 'Department of Theology, } \\
\text { Pontificia Universidad } \\
\text { Javeriana, Bogotá, Colombia }\end{array}$} \\
\hline \multicolumn{2}{|c|}{$\begin{array}{l}{ }^{2} \text { Department of Theology, } \\
\text { Universidad Pontificia } \\
\text { Bolivariana, Medellín, } \\
\text { Colombia }\end{array}$} \\
\hline \multicolumn{2}{|c|}{$\begin{array}{l}\text { Corresponding author: } \\
\text { Carolina Vila Porras, } \\
\text { cvpcsdop@gmail.com }\end{array}$} \\
\hline \multicolumn{2}{|c|}{$\begin{array}{l}\text { Dates: } \\
\text { Received: } 14 \text { Mar. } 2020 \\
\text { Accepted: } 17 \text { July } 2020 \\
\text { Published: } 23 \text { Sept. } 2020\end{array}$} \\
\hline \multicolumn{2}{|c|}{$\begin{array}{l}\text { How to cite this article: } \\
\text { Vila Porras, C. \& Toro-Jaramill, } \\
\text { I.D., 2020, 'The ethical and } \\
\text { spiritual considerations of } \\
\text { Matthew's Beatitudes: } \\
\text { Configuration of the human } \\
\text { being in companies', Verbum } \\
\text { et Ecclesia 41(1), a2090. } \\
\text { https://doi.org/10.4102/ } \\
\text { ve.v41i1.2090 }\end{array}$} \\
\hline \multicolumn{2}{|c|}{$\begin{array}{l}\text { Copyright: } \\
\text { (C) 2020. The Authors. } \\
\text { Licensee: AOSIS. This work } \\
\text { is licensed under the } \\
\text { Creative Commons } \\
\text { Attribution License. }\end{array}$} \\
\hline \multicolumn{2}{|c|}{ Read online: } \\
\hline 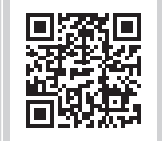 & $\begin{array}{l}\text { Scan this QR } \\
\text { code with your } \\
\text { smart phone or } \\
\text { mobile device } \\
\text { to read online. }\end{array}$ \\
\hline
\end{tabular}

Most organisations consider human beings as a resource, a position that adopts a functionalist perspective and focuses on ways in which companies operate. The purpose of this study is to expose the type of human being that is configured in the light of the ethical-spiritual that can be deduced from the text of the Matthean Beatitudes. On reviewing the literature related to 'organisations and spirituality', several studies related to humanism, business, religion and spirituality were found. However, the absence of a study from the theological-biblical viewpoint in association with the business field was observed. A general conclusion deduced after using the hermeneutics of Matthew 5:3-10 is that from the Beatitudes, spiritual growth of individual and community is possible, thus enabling to understand the type of human resource that is required by companies today. Moreover, the unacceptable conviction or practice that human beings are considered as a resource or means, and not, as will be argued in the study, as beings recognised and treated as an end in themselves forms the basis of this study. This problem is critically addressed from the Christian ethical-spiritual approach that is constructed from the theological hermeneutics of the Matthean Beatitudes.

Intradisciplinary and/or interdisciplinary implication: The context from which the research is undertaken takes as vantage point the unacceptable conviction or practice that human beings are considered as a resource or a means, and not, as will be argued in the article, as beings recognised and treated as an end in themselves. The unacceptable contextual reality is critically addressed from both a Christian ethical-spiritual itinerary that is constructed from the theological hermeneutics of the Matthean beatitudes as well as in dialogue with the business reality, specifically business administration.

Keywords: spirituality; ethics; employee spirituality; organisational development; values; leadership.

\section{Introduction}

Most companies consider human beings as a resource (Pirson 2016:1-7; Toro-Jaramillo \& Ramírez 2017); this position adopts a functionalist perspective and focuses on how companies operate. This is well explained by Saldarriaga Ríos (2014) when he says that:

$[A]$ dministration has been defined in different ways over time and one of the conceptualizations that has lasted and is widely shared in academic and business scenarios is that it is in charge of planning, organizing, directing and controlling the organization's resources. From this conception it is also that which places it as an activity of an instrumental nature in which the human being is considered only a resource for production and in which there is an almost total absence of humanization. (p. 224)

Hence, Saldarriaga goes on to explain that, according to Aktouf (1998):

$[C]$ ompanies must stop considering human beings as machines and disposable resources and recognize in them the subjectivity, the particularity that makes them need to be valued in all their dimensions and not only in the productive aspect. (Saldarriaga Ríos 2014:225)

\section{Also from (Saldarriaga Ríos 2014):}

[T] he postulates of Taylor and Fayol, the Administration of companies has conceived the human being, in the best of cases, as a tool for work and with the postulates of Weber (1961) about the ideal type of structuring of the society and the organization and the need for rationalization of production, this conception is strengthened and the human being is conceived as one more part of the gear of the company, which must be controlled by virtue of the organizational efficiency. These The same postulates are shared 
by Klisberg (1995), for whom the human being is only an element that is willing to favour the productive process. (p. 225)

Encountered with this situation, the following question arises: How can humans be understood today in the world of companies from an ethical-spiritual standpoint on the basis of the discourse of Matthew's Beatitudes? It is important to note that this question is asked from a theological perspective. Therefore, the ethical-spiritual point of view that is extracted from the Beatitudes allows the study to have a theological look.

Several strategies and spiritual proposals (Ayoun, Rowe \& Yassine 2015:938-957; Benefiel, Fry \& Geigle 2014:175-187; Corner 2009:377-389; Gotsis \& Kortezi 2008:575-600; Groen 2008:193-204; Karakas, Sarigollu \& Uygur 2017:731-744; Lychnell 2017:255-275; Poole 2009:577-588; Roof 2015:585-599; Sandelands 2017:771-780; Vilmante 2014:1205-1212; Weinberg \& Locander 2014:391-408) adopted in the business field have contributed to the growth of human beings and positioned them within the organisational sphere, seeking not only their well-being but also greater sustainability and productivity of companies (Toro-Jaramillo \& Ramírez 2017), which is achieved from individual (Brophy 2015:779-794; Kolodinsky, Giacalone \& Jurkiewicz 2008:465-480; Roof 2015:585-599) and community (Castrillón 2011:34-55) spiritual lives.

Moreover, the implementation of these spiritual proposals in companies (Ayoun et al. 2015:938-957; Brophy 2015:779-794; Roof 2015:585-599) has achieved a more positive organisational environment (Pandey, Gupta \& Arora 2009; Weinberg \& Locander 2014:391-408), where institutional dynamics strengthen the spiritual dimensions of human beings and thus impact their work (Lynn, Naughton \& VanderVeen 2009:227-243; Poole 2009:577-588; Yazdani \& Murad 2014:399-417).

In viewpoint of the above, after employing different search equations whilst reviewing scientific databases - Scopus (humanism, business, company, religion and spirituality), Web of Science (spirituality and business) and Ebsco (humanism, business, religion and spirituality) - we identified the research gap with respect to these subject areas because although studies related to ethics in general, business ethics and even spirituality prevail, inadequate research prevails with respect to companies' biblical viewpoints. This study takes into account the ethical and spiritual considerations proposed in the text of Matthew 5:3-10, in order to help identify the type of human resources required in business today.

The first part of the study infers the ethical-spiritual considerations of the discourse of Matthew's Beatitudes as this is how, in early stages, we can understand the role of biblical theology in the specific reality of companies and simultaneously realise how this reality can be enriched by being challenged by the context (Andiñach 2012:33-35). Finally, through this knowledge, the following hypothesis will be validated: The ethical and spiritual considerations inferred from Matthew's Beatitudes contribute to the understanding of kinds of human beings required in today's business world.

Understanding the ethical-spiritual aspect of Matthew's Beatitudes, together with various investigations conducted in the field of companies and spirituality, allows and favours a configuration of the human factor in today's companies.

The study is divided into two parts and ends with the conclusions. Part 1 presents a contextualisation of Matthew's Beatitudes, and Part 2 elaborates on the human factor in companies, beginning with the ethical-spiritual aspect inferred from Matthew's Beatitudes.

\section{Contextualisation of Matthew's Beatitudes}

Before categorising the ethical-spiritual aspect of the Beatitudes discourse, it is necessary to contextualise them to have a broader vision of the subject to be addressed.

The content of Chapters 5-7 of Matthew's gospel raises one of the most important and meaningful directions of Jesus: the inauguration of the Kingdom of Heaven (Acosta 2003:319-320).

The Beatitudes are the first of the five programmatic speeches of Jesus (Acosta 2007) found in Matthew 5:3-10. ${ }^{1}$ The word macarism translates as beatitude, praise and congratulation (Coenen, Beyreuther \& Bietenhard 2012:182). The main or basic term from which Bible study commences is macarius, which translates as blessed, happy and joyful (Coenen et al. 2012:182). Therefore, the text of Matthew 5:3-10 is determined by the term macarius.

With respect to the relationship between the Matthew 5:3-10 passage and the whole of Matthew's Gospel, one relevant fact is discovered, that is, Jesus announces his first speech as Master immediately after three events, namely the Baptism (Mt 3:13-17), the temptations in the desert by the devil (Mt 4:1-11) and the call he makes to four people who will then become his disciples (Mt 4:18-21). It may then be inferred that the evangelist shows an attempt to situate the teaching of Jesus on the Mount after the other two passages. In addition, through this speech, Jesus intends to teach the fulfilment of the scriptures and the renewal of the Covenant (Kapkin 2003:149).

Therefore, the Beatitudes constitute a speech given by Jesus to his disciples and the people to guide them on how to build happiness. Both Matthew and Luke express that (Vila 2013):

[T] he Kingdom of Heaven is a reality already acquired, it is current, it is present, it is happening now; this is confirmed in the conjugation of the verb to be (is), found in Verses 3 and 10 of Matthew ... (p. 184)

1.Texto analizado exegéticamente por Carolina Vila Porras en: 'Ser cristiano hoy: propuesta humanizadora en Mt 5, 3-10' (Trabajo de grado de la Maestría en Teología). 
Therefore, the task consists in interpreting the text.

Moreover, the audience of Matthew 5:3-10 comprises people from all over the territory of Palestine (Cardona \& Oñoro 2011). Thus, it can be said that the audience listening to this discourse evokes the idea of unity amongst all peoples. At the same time, Matthew 4:18-22 mentions four disciples whom Jesus calls to his mission: Simon, Andrew, James and John. This passage is part of the remote context of Matthew 5, 3-10 that helps understand that the text is addressed to these four disciples and to all the people who receive the message.

Otherwise, according to Matthew, macarisms are conditions to be admitted to the Kingdom of Heaven, and they have a paraclétic orientation (Levoratti 2007). That is to say, they seek to guide the life of Christians and all those who want to initiate the process of following Jesus or who believe that they have an ethical life. Hence, it is reasonable to seek an ethical-spiritual proposal for companies from Beatitudes. Similarly, those who are called happy or blessed in the Beatitudes are people who find themselves are in a situation that is the opposite to being happy or blessed. The authority with which Jesus proclaims the macarisms comes from his role as rabbi, as Messiah, because of the miracles he has previously performed and also because of the support he receives from his disciples.

This authority exercised by Jesus allows the message conveyed to be more acceptable for his audience.

With all of the above, the literary intention of evangelists is followed, suggesting that Jesus is followed not only because of his well-elaborated speeches but because they are preceded by works previously conducted on the audience.

In relation to the sitz im leben ('life context') (Aletti et al. 2007:37), it is worth remembering that Matthew is writing for an already established Christian community, mainly possessing Jewish and (to a lesser extent) pagan roots (Rodríguez 2006:14). It is important to note that this particular community is valid for all peoples. Hence, this community begins to establish itself as a church and aims to strengthen its new identity as Jesus' followers shortly after the break with Judaism, a circumstance that left them in a situation of social, cultural and religious marginalisation. Consequently, it is likely that these blessed people were actually poor, persecuted and disadvantaged. Once the context has been explained, it is possible to understand that Matthew guides his community to discover, amid adversity, the values of the Kingdom of God (Vila 2017:78).

In short, the macarisms in Matthew's speech are addressed to a group of people who have suffered marginalisation and are promised that they will not be abandoned. Consequently, these poor people, in accepting Jesus' message, experience the presence of the Kingdom of Heaven, and this encourages them to exhibit the rewards of the Kingdom to others through their actions (Rodríguez 2006:20).

\section{Human beings in companies, from the viewpoint of the ethical and spiritual considerations inferred from Matthew's Beatitudes}

The challenge of this section aims to describe the type of human being that is configured in light of the text. To achieve this purpose, we present a contextualisation of the studies conducted and published in various databases associated with companies and spirituality areas. This aspect will allow us to illustrate the human being shaped within companies and to link this individual to the deductions of Matthew's Beatitudes.

Some of the realities of the companies found through the systematic literature review are related to difficulties in leadership, and the human factor is considered as a resource and not as the core of the organisation, that is, as a means and not as an end in itself. Moreover, in business, ethics are implemented without an explicit articulation with Christian ethics, alongside, amongst other things, the alienation of human beings at workplace, individualism and incapacity to establish an organisational environment based on the quality of interpersonal relationships. Additionally, administrative professionals, who have been trained to solve the operations of companies, have lacked humanistic training. This factor has resulted in the current business model, where the human factor is not at the core of business practices.

These troublesome realities in companies have been studied since approximately the 13th century, with major developments over the four following centuries and particularly over the past century. Some studies (Hendar \& Ferdinand 2017:78-102; Lychnell 2017:255-275; Moya 2014:817-831; Melé \& Fontrodona 2017:671-679; Melé \& Schlag 2016:181-183; Rothausen 2017:811-829) conducted so far link companies or workplaces to spirituality; Christian ethics and social responsibility; leadership connected with spirituality; and sustainability and productivity (Toro-Jaramillo \& Ramírez 2017) with organisational culture achieved from an individual's (Brophy 2015:779-794; Kolodinsky et al. 2008:465-480; Roof 2015:585599) spiritual life than their community lives (Castrillón 2011:34-55). In this context and from what is analysed in the biblical text, we seek to illustrate the status of the human factor within companies.

When spirituality is linked to the corporate culture, the organisational vision shifts, and therefore, both spirituality and corporate sustainability are linked to a higher productivity. The contribution is related to inferring the ethical-spiritual aspect from Matthew's Beatitudes in relation to the real requirements of companies, which, in turn, allow placing human beings at the core of companies, thereby creating a new business style. 
Various investigations (Ananthram \& Chan 2016:843-880; Ayoun et al. 2015:938-957; Benefiel et al. 2014:175-187; Brophy 2015:779-794; Corner 2009:377-389; Groen 2008:193-204; Karakas 2010:89-106; Karakas et al. 2017:731-744; Kolodinsky et al. 2008:465-480; Lynn et al. 2009:227-243; Poole 2009:577588; Roof 2015:585-599; Stuart \& Peter 2017:216-224; Tourish \& Tourish 2010:207-224; Vilmantè 2014:1205-1212; Wahid \& Mustamil 2017:263-280; Weinberg \& Locander 2014:391-408) have been conducted in this field using different strategies and spiritual proposals, which have favoured the development of human beings and their position in the business field (Ayoun et al. 2015:938-957; Benefiel et al. 2014:175-187; Corner 2009:377-389; Gotsis \& Kortezi 2008:575-600; Groen 2008:193-204; Karakas et al. 2017:731-744; Lychnell 2017:255-275; Poole 2009:577-588; Roof 2015:585-599; Sandelands 2017:771-780; Vilmantè 2014:1205-1212; Weinberg \& Locander 2014:391-408). Through these implementations, not only human well-being but also greater sustainability and productivity in the companies were achieved. Furthermore, through the implementation of these spiritual proposals, a more authentic organisational environment has also been created wherein institutional policies are formulated so that human beings enhance their spiritual dimension, thereby favouring their work (Yazdani \& Murad 2014:399-417).

In relation to this study, from the evangelical Beatitudes speech, the ethical-spiritual aspect is proposed because it allows placing the human factor at the core of today's business practice. Particularly, this aspect materialises through each of the Beatitudes.

A key to the text of Matthew's Beatitudes, as already stated, is the term macarius, which translates to 'Blessed is he who ... (Balz \& Schneider 2002:129)'. At first, macarisms begin with a happiness proclamation, ensuring that they are directed at certain people and enabling to perceive the condition announcing the action (Balz \& Schneider 2002:129). Furthermore, each Beatitudes present a contradiction between the happiness proposed by Jesus in the first part of each verse and the subjects he designates as blessed because they are currently experiencing negative life scenarios.

In the words of Marías (1987:107), the Beatitudes refer to eight modes of happiness, which are initially independent, and each of these forms could be related to life attitudes or to each human being. Then, the ethical-spiritual aspect of each beatitude is proposed to identify the type of human being that is shaped today within companies.

In the first beatitude, Blessed are the poor in spirit, for theirs is the Kingdom of Heaven (Mt 5:3), ${ }^{2}$ the poor in spirit are those who are aware that they depend completely on God's mercy. It refers to an inner attitude of abandonment and trust in God as a consequence of choosing the Kingdom. The condition in this beatitude is that these people are poor, so 2.Todas las bienaventuranzas están tomadas de: Biblia de Jerusalén (1975). how are they called happy? The 'poor' in this case are those who live in oppressive situations. In association with the expression 'in spirit', it is understood that those who have no other hope but God are blessed (Vila 2017:86-87). Moreover, the 'Kingdom of Heaven' is already present and active, and it is for those who live in oppressive conditions but do not lose their hope and believe that God will help them (Vila 2017:88).

The poor have to deal with various oppressive situations whilst working; however, such situations cause them to experience the inner attitude of abandonment and develop the required trust and hope about God. This attitude can, at the same time, aid in facing difficulties that are experienced in leadership and interpersonal relationships within an organisation.

In the case of the second beatitude, Blessed are those who mourn, for they shall be comforted (Mt 5:4), 'the meaning reflected in Matthew 5:4 is to be sad, to grieve, mourn someone's death'. It is a state of suffering. Here, the evangelist (Camacho 1986):

$[R]$ efers to a group of people undergoing intense pain while suffering due to the realities of this world and manifest it through tears, gestures, or words and in turn place all their hope in God (p. 66).

In this beatitude, although there prevails a contradiction in the first part of the verse, that is, the happiness proposed by Jesus and the people who cry because of their intense sufferings, the latter part, 'they shall be comforted', reflects hope. In this case, those who weep will be comforted by God. This macarism reflects the hope of human beings, who, although are sad, afflicted, or in a state of pain because of work or other harsh realities, will be comforted by the other, by God. Being open to live as an individual and in a community based on these spiritual presumptions can contribute to human growth within companies and strengthen them whilst facing life's diverse circumstances.

In the third beatitude, Blessed are the meek, for they shall inherit the earth (Mt 5:5), meek means 'gentle, humble, kind, or considerate (Bible Works (version 7) 2007)'. These qualities are attributed to people. This macarism describes the meek and humble as happy, and there is no contradiction between the subject and the happiness that individual will receive.

The second part of this beatitude suggests that the action falls on the subject; it is strictly up to the subject to achieve the promise, that is, inheriting the earth, and the subject is the protagonist who makes and deserves the promise (Vila 2017:90). The earth will be inherited by the meek without resorting to violence or other similar means to achieve it, as it will be God's gift to them, because they strive to achieve their goals without causing any harm or violence.

Ultimately, human beings possessing attributes such as humility, gentleness and meekness will achieve their desires 
because they do not resort to force or violence and abide by the rules established by the companies.

In the fourth beatitude, Blessed are those who hunger and thirst for justice, for they shall be satisfied (Mt 5:6), the term 'justice' is understood as the justice of the Kingdom. Justice is explained by Jesus through his actions and his preaching. In other words (Vine 1999):

[T]he meaning of justice in Mt 5:6,10 and 20 has to do with everything that is just in itself, upright, everything that is in accordance with the revealed will of God. (p. 477)

Furthermore, just as in the case of the previous beatitude, this one also involves a promise of salvation; however, in this case, the future tense of the verb is stated, that is, 'will be satiated'; and therefore, it is suggested that the subjects mentioned in the macarism are awaiting justice (Vila 2017:94). However, the contradiction between the situation experienced by the subjects and the proclamation of happiness that befalls them is reflected again.

It could even be inferred that this macarism is a response to the unjust realities experienced by the subjects of the Beatitudes (verses 4-5). With this beatitude, the first group of macarisms is concluded (verses 4-6), thereby expressing human and spiritual requirements in expecting eschatological happiness that has already begun with the proclamation but has not yet reached its fullness (Vila 2017:94).

The fourth macarism focuses on those who want to live by relying on the justice of the Kingdom, that is, on everything that is just and right in itself. According to the text, the beatitude describes a group of people who are waiting for justice because they are experiencing unjust situations. It can be inferred that if the justice of the Kingdom is lived, eschatological happiness begins to develop. In an organisation where justice prevails, it is possible to create an environment that favours human and family or interpersonal relationships.

The fifth beatitude, Blessed are the merciful, for they shall obtain mercy (Mt 5:7), contains the adjective 'merciful' that is being used as a noun in the given context, reflecting an attitude and regular activity of the subject. 'It is a question of (...) a quality in action that manifests itself in relation to one's neighbor in need and aims at eliminating their needs' (Camacho 1986:141). It refers to a group of people, who, because of their attitude, regularly facilitate any kind of help to those in need. It is not clear as to what kind of activity the subjects perform to help their neighbours; therefore, it refers to any merciful behaviour in a broad sense (Camacho 1986:141). The sense of being merciful is thus a human attribute that can be highlighted.

In this macarism, unlike the previous ones, there prevails a complementary relationship between the first and second parts of the macarism, suggesting that those who offer any kind of help to their needy neighbours, will always, in turn, receive what they need through divine help (Camacho 1986:142). In other words, this idea means that those who practice mercy will receive divine mercy. At the same time, it can be observed that the subject is waiting to attain God's grace as the promised divine happiness because this happiness is something the subject may receive in the future.

Therefore, through this beatitude, a human being with the quality of regularly helping those in need, in a broad sense of the expression, is understood. Thus, it can be deduced that the merciful can be those who are always available to lend a helping hand at their workplaces, without discriminating. They are those who know how to walk in other's shoes and experience their suffering as their own. They demonstrate this by taking action in the face of a critical situation.

Mathew states the sixth macarism, Blessed are the pure in heart, for they shall see God (Mt 5:8), for a Christian community with a strong Jewish tradition as this community emerged from Judaism (Rodríguez 2006:14). Therefore, this expression 'pure in heart' is contrary to Matthew's ritual-centric community. For his community, the meaning of ritual purity is very lucid, but in Jesus' words, Matthew aims at emphasising that it is not about ritual purity but purity of the heart, suggesting that one should have a pure heart before God (Rodríguez 2006:65).

The expression 'they shall see God' is the prize or reward for being pure at heart; it does not stem from the belief of Judaism that states that whoever sees God can die. In Judaism, to be in a communion with God, purity must be attained through rituals; if an impure act is committed, it must be purified ritually. Through this practice, one does not get to see God, one simply worships him.

Through Matthew, Jesus wants to express that those pure at heart do not have to worship, which is a mediation stage, God but rather directly meet God, are in the presence of God, see him face to face, and this constitutes a promise for those who have a clean heart.

Consequently, this macarism eliminates external or merely physical purity and highlights being pure on the inside; therefore, only those with a pure heart will be able to contemplate the face of God. This beatitude clearly raises the ethical path that Matthew proposes throughout his gospel, and through this beatitude, the path becomes even more specific, suggesting individuals to attain the state of inner purity (Camacho 1986:144).

It can then be deduced that those pure at heart determine to stay in this state, delivering justice before the others and aim at seeing God. The macarism gives us a glimpse of the results of sustaining inner purification, which will be reflected in the practices of those pure at heart whilst delivering justice or being just towards their neighbour and thereby see God - an aspect that is impossible according to fundamentalist Judaism (Vila 2017:98).

The sixth beatitude therefore suggests that human beings should work towards achieving the state of inner purity to 
contemplate the face of God; this inner purity can thus be reflected whilst being justice to one's neighbour or colleagues in and out of the organisation.

With respect to the seventh macarism, Blessed are those who work for peace, for they will be called children of God (Mt 5:9), if one thinks from the Semitic viewpoint, peace is not only the opposite of war, but it is also an aspect that contributes towards maintaining a good relationship with oneself, nature, others and God, ultimately contributing to brotherhood and seeking salvation (Camacho 1986:149). When this beatitude speaks about those who work for peace, it not only refers to those who avoid war or fight, but also to the constant search for elements that enable humanity to multiply the aspects that contribute to salvation and prevent wars. Therefore, this macarism designates people devoted to establish peace, a phenomenon that is developed by subjects rather than being a quality (Camacho 1986:149).

Moreover, those who work for peace are proclaimed to be happy and, as in the previous Beatitudes (4-8), will be called children of God (Camacho 1986:149), thus materialising the promise and inviting human beings to work towards promoting peace amongst themselves and eliminating all the difficulties that prevent it. Therefore, establishing peace or working for it entails, opening paths of liberation facilitate justice for human beings who are oppressed, enslaved and facing unjust treatments (Vila 2017:99).

With this macarism, the series that began from Matthew 5:7, which identifies those who work for peace and will be called children of God, is concluded. The appellation children of God projects the father-son relationship between those who work for peace and God, which is '[...] formed due to the peace existing between them (Camacho 1986:150)'.

In brief, an analysis of those who work for peace suggests that in this macarism, no contradiction prevails between the first and second parts, and the action performed in the first part generates a promise in the second (Camacho 1986:150). Finally, working to create peace constitutes a path that begins with rescuing human beings from oppression, slavery, injustice, lack of love and all kinds of actions that favour dehumanisation (Mt 5:4-9) to further achieve salvation and thus sustain and nurture humanity.

The seventh beatitude therefore encourages human beings to sustain a good relationship with themselves, nature, others and God. Thus, human beings should strive to works towards building peace and creating paths of liberation, justice and humanisation that directly impact the organisational and family environment.

In the eighth macarism, Blessed are those who are persecuted for righteousness' sake, for theirs is the Kingdom of Heaven (Mt 5:10), we need to differentiate between the term righteousness stated in Matthew 5:6 and 5:10 because although both the verses talk about righteousness, the context in which the term has been used differs. In Matthew 5:6, being righteous refers to seeking justice and restoring the rights of the oppressed and those who have been violated and suppressed. Moreover, efforts of such righteousness, in this macarism, are rewarded by God. However, in the case of Matthew 5:10, righteousness, as a virtue, means to work to seek justice for others. Further, in the second part, the macarism states that the Kingdom of Heaven belongs to those who are persecuted for righteousness' sake, and therefore, it can be deduced that Matthew 5:6 entails being righteous to seeks God's Kingdom and illustrate one's relationship with God, whilst Matthew 5:10 reveals not only this aspect but firstly emphasises pursuing justice for neighbours and one's relationship with them (Camacho 1986:152).

When the expression those persecuted for the sake of justice is carefully analysed and related to the previous macarism (5:3-9), it can be inferred that those persecuted are people who choose to follow the path of justice, that is, the manner of living that Jesus presented in the Beatitudes (Rodríguez 2006:66). Thus, the persecuted are people who have chosen and accepted the message of Jesus; moreover, they have remained faithful to that path of justice, as a result of which, the Kingdom of God is for them, and therefore, they are the blessed.

According to Matthew, the persecuted, more particularly, according to Matthew 5:10, are those who suffer all kinds of oppression for having chosen, accepted and remained faithful to Jesus' way of living and who, in spite of the persecution, remain steadfast on that path. The novelty of this beatitude is that those who are persecuted are not persecuted only for the sake of social or judicial justice but also for the justice of the Kingdom; in other words, they are persecuted for having chosen the Kingdom, which is neither of this world, nor is it like the Kingdom of Herod, regarded to be the Great; Herod's greatest concern was to annihilate every possible internal adversary that was raised against his reign, and he even orders the death of his possible rivals (Jeremías 1977), an image that matches the one conveyed in the gospel of Matthew (Mt 2:13-18), concerning the killing of the innocent.

Those who are persecuted for accepting Jesus' message and adhering to it live in a Kingdom of divine justice are humble enough to live in the Reign of God. In other words, whoever chooses the path of the Kingdom knows that their life will be a continuous journey of humanisation that begins with being humble (Mt 5:3), continues in an identification of the son or daughter of the Heavenly Father (Mt 5:4-6) and later preaches or spreads the Good News (Mt 5:7-9), thereby revealing their loyalty to the Kingdom of God (Jeremías 1977:158).

Thus, the eighth beatitude portrays human beings as workers for the justice of other people and their relationship with God. If they are persecuted for this cause, it means that 
they have chosen the path of humanisation proposed by the gospel.

In brief, the ethical-spiritual aspect that is inferred from Matthew's Beatitudes helps to understand the configuration of human beings in today's companies as being on the path of liberation from different oppressions, sufferings, injustices and the slavery of society. Matthew's ethical-spiritual path ascribes human beings to possessing greater trust and being more promising, empathetic, meek and just. This path also encourages human beings to evaluate their actions through introspective and critical analysis; therefore, the path offered by Matthew's Beatitudes is, in the end, a path of humanisation that is open to all those who believe that it is important to build a more just and humane society.

\section{Conclusion}

By virtue of all the above, we understand that human beings are open to follow a transformation path where their spiritual experience is associated with their work. The possibilities for individual's and community's spiritual growth stem from the Beatitudes, which, in turn, help understand the types of human being required by current companies.

Human beings who are shaped by the hermeneutics of the biblical text are characterised by having an attitude of ongoing openness to transformation and building confidence as a quality in association with being inside and outside of the workplace. Moreover, abandonment constitutes a way of standing up to the various situations of oppression that may arise at workplaces.

In the face of sufferings or difficulties that may be experienced in the organisational environment, a possibility of waiting for God to provide the required comfort that heals wounds and strengthens one's spirit exists.

The human being who is configured in the light of the Matthew's Beatitudes is a kind, humble, delicate and considerate person who is capable of achieving goals without force or violence. Such a person who works in the business field fights against the unjust realities that are contrary to the values of the Kingdom.

Human beings in companies should be merciful and develop a helpful attitude towards those in need; such attributes are revealed by sharing the burden of other individuals.

Moreover, a person who works in companies that follow the hermeneutics of the text is encouraged to build inner purity, suggesting that a person's nature should be in accordance or consistent with the person's actions.

Human beings who work in companies establish peace when their actions are directed towards fighting against problems, such as slavery, injustice and oppression and lack of love, which threaten the prevalence of humanisation.

To summarise, we understand that human beings have the purpose of living coherently in their relationship with God, themselves, nature and others.

\section{Acknowledgements}

This article is the result of research: 'Ethical-Spiritual Itinerary for Organizations. A hermeneutic proposal based on the Beatitudes of Matthew'.

The authors thank the CIDI of the Universidad Pontificia Bolivariana Medellín-Colombia, for the financial support of the research project, and Father Iván-Darío Toro-Jaramillo, who is the director of the research, for the accompaniment process.

\section{Competing interests}

The authors declare that no conflict of interest exists.

\section{Authors' contributions}

C.V.P. is the principal researcher, and I.D.T-J. is the director of the investigation. All authors have read and agreed to the published version of the manuscript.

\section{Ethical consideration}

Approval to conduct the study was received form the Universidad Pontificia Bolivariana Medellín-Colombia (reference: CIDI 803B-06/17-14).

\section{Funding information}

Financial support for the study the Universidad Pontificia Bolivariana Medellín-Colombia.

\section{Data availability statement}

Data sharing is not applicable to this article as no new data were created or analysed in this study.

\section{Disclaimer}

The views and opinions expressed in this article are those of the authors and do not necessarily reflect the official policy or position of any affiliated agency of the authors.

\section{References}

Acosta, R., 2003, 'Justicia y reino de los cielos: Análisis literario de las bienaventuranzas de Mateo' [Justice and the Kingdom of Heaven: A Literary Analysis of the Beatitudes of Matthew], Theologica Xaveriana 147(2003), 319-320.

Acosta, R., 2007, Justicia y reino de los cielos en las bienaventuranzas de Mateo [Justice and Kingdom of Heaven in the Beatitudes of Matthew], Pontificia Universidad Javeriana, Bogotá

Aletti, J.-N., Gilbert, M., Ska, J-L. \& De Vulpillières, S, 2007 , Vocabulario razonado de la Exégesis Bíblica, Los términos, las aproximaciones, los autores [Reasoned Vocabulary of Biblical Exegesis, the terms, the approaches, the authors], Verbo Divino, Navarra. 
Aktouf, O., 1998, La administración: entre tradición y renovación (3a ed.) [Administration: between tradition and renewal (3rd edn.)], Cali: Artes Gráficas del Valle.

Ananthram, S. \& Chan, C., 2016, 'Religiosity, spirituality and ethical decision-making: Perspectives from executives in Indian multinational enterprises', Asia Pacific Journal of Management 33(3), 843-880. https://doi.org/10.1007/s10490-0169460-5

Andiñach, P., 2012, Introducción hermenéutica al Antiguo Testamento [Hermeneutic introduction to the Old Testament], Verbo Divino, Navarra.

Ayoun, B., Rowe, L. \& Yassine, F., 2015, 'Is workplace spirituality associated with business ethics?', International Journal of Contemporary Hospitality Management 27(5), 938-957. https://doi.org/10.1108/IJCHM-01-2014-0018

Balz, H. \& Schneider, G., 2002, Diccionario exegético del Nuevo Testamento $(\lambda-\omega)$ [Exegetical Dictionary of the New Testament $(\lambda-\omega)$ ], Ediciones Sígueme, Salamanca.

Bible Works version 7, 2007, computer software, Bible Works LLC, Norfolk, Virginia.

Biblia de Jerusalén, 1975, Desclée de Brouwer, Bilbao.

Benefiel, M., Fry, L. \& Geigle, D., 2014, 'Spirituality and religion in the workplace: History, theory, and research', Psychology of Religion and Spirituality 6(3), History, theory, and research', Psychology
175-187. https://doi.org/10.1037/a0036597

Brophy, M., 2015, 'Spirituality incorporated: Including convergent spiritual values in business', Journal of Business Ethics 132(4), 779-794. https://doi.org/10.1007/ s10551-014-2337-y

Camacho, F., 1986, Análisis semántico y comentario exegético de las bienaventuranzas de $M t 5$ [Semantic analysis and exegetical commentary on the Beatitudes from Mt 5: 3-10], 3-10, Cristiandad, Madrid.

Cardona, H. \& Oñoro, F., 2011, Jesús de Nazareth en el evangelio de San Mateo [Jesus of Nazareth in the Gospel of Saint Matthew], Universidad Pontificia Bolivariana, Medellín.

Castrillón, D., 2011, 'Del líder humano en la organización' [of the human leader in the organization], Pensamiento y gestión 31(2011), 34-55.

Coenen, L., Beyreuther, E. \& Bietenhard, H., 2012, Diccionario Teológico del Nuevo Testamento (M-Z) [Theological Dictionary of the New Testament (M-Z)], vol. II, Ediciones Sígueme, Salamanca.

Corner, P., 2009, 'Workplace spirituality and business ethics: Insights from an Eastern spiritual tradition', Journal of Business Ethics 85(3), 377-389. https://doi.org/ 10.1007/s10551-008-9776-2

Gotsis, G. \& Kortezi, Z., 2008, 'Philosophical foundations of workplace spirituality: A critical approach', Journal of Business Ethics 78(4), 575-600.

Groen, J., 2008, 'Workplace spirituality and organizational commitment: An empirical study', Journal of Organizational Change Management 13(2), 193-204. https:// doi.org/10.1108/09534810810847039

Hendar, H. \& Ferdinand, A.T., 2017, 'Introducing the religio-centric positional advantage to Indonesian small businesses', Management and Marketing 12(1) 78-102. https://doi.org/10.1515/mmcks-2017-0006

Jeremías, J., 1977, Jerusalén en tiempos de Jesús [Jerusalem in the time of Jesus], Cristiandad, Madrid.

Kapkin, D., 2003, Mateo 1-16. El evangelio del reino [The gospel of the kingdom], Fundación Universitaria Luis Amigó, Medellín.

Karakas, F., 2010, 'Spirituality and performance in organizations: A literature review', Journal of Business Ethics 94(1), 89-106. https://doi.org/10.1007/s10551-0090251-5

Karakas, F., Sarigollu, E. \& Uygur, S., 2017, 'Exploring the diversity of virtues through the lens of moral imagination: A qualitative inquiry into organizational virtues in the Turkish context', Journal of Business Ethics 141(4), 731-744. https://doi. org/10.1007/s10551-016-3150-6

Kolodinsky, R., Giacalone, R. \& Jurkiewicz, C., 2008, 'Workplace values and outcomes: Exploring personal, organizational, and interactive workplace spirituality', Journal of Business Ethics 81(2), 465-480. https://doi.org/10.1007/s10551-007-9507-0

Levoratti, A., 2007, 'Evangelio según san Mateo', A. Levoratti, E. Tamez \& P. Richard (eds.), Comentario Bíblico Latinoameriacano Nuevo Testamento [Latin American Biblical New Testament Commentary], 277-400. Verbo Divino, Navarra.

Lychnell, L., 2017, 'When work becomes meditation: How managers use work as a tool for personal growth', Journal of Management, Spirituality and Religion 14(3) 255-275. https://doi.org/10.1080/14766086.2017.1307782
Lynn, M., Naughton, M. \& VanderVeen, S., 2009, 'Faith at work scale (FWS): Justification, development, and validation of a measure of Judaeo-Christian Justification, development, and validation of a measure of Judaeo-
Religion in the workplace', Journal of Business Ethics 85(2), 227-243.

Marías, J., 1987, La felicidad humana [Human happiness], Alianza Editorial, Madrid.

Melé, D. \& Schlag, M., 2016, 'Humanism in economics and business. Perspectives of the Catholic social tradition', Empresa y humanismo 19(2), 181-183. https://doi. org/10.1007/978-94-017-9704-7

Melé, D. \& Fontrodona, J., 2017, 'Christian ethics and spirituality in leading business organizations: Editorial introduction', Journal of Business Ethics 145(4), 671-679. https://doi.org/10.1007/s10551-016-3323-3

Moya, A.R., 2014, 'Religion in companies: Conflicts and solutions. La religión en la empresa: Problemas y soluciones', Estudios Eclesiásticos 89(351), 817-831.

Pandey, A., Gupta, R. \& Arora, A., 2009, 'Spiritual climate of business organizations and its impact on customers experience', Journal of Business Ethics 88(2), 313-332. https://doi.org/10.1007/s10551-008-9965-z

Pirson, M., 2016, 'Editorial: Welcome to the humanistic management', Journal, Humanistic Management Journal 1(2016), 1-7. https://doi.org/10.1007/s41463016-0001-7

Poole, E., 2009, 'Organisational spirituality - A literature review', Journal of Business Ethics 84(4), 577-588. https://doi.org/10.1007/s10551-008-9726-z

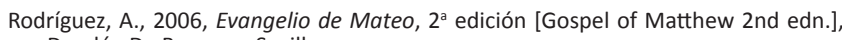
Desclée De Brouwer, Sevilla.

Roof, R., 2015, 'The association of individual spirituality on employee engagement: The spirit at work', Journal of Business Ethics 130(3), 585-599. https://doi. org/10.1007/s10551-014-2246-0

Rothausen, T., 2017, 'Integrating leadership development with Ignatian spirituality: A model for designing a spiritual leader development practice', Journal of Business Ethics 145(4), 811-829. https://doi.org/10.1007/s10551-016-3241-4

Saldarriaga Ríos, J.G., 2014, 'La concepción del sujeto en la administración: Una mirada desde la gestión humana' [The conception of the subject in administration: A view from human management], Dialnet 14(1), 223-237.

Sandelands, L., 2017, 'The real mystery of positive business: A response from Christian faith', Journal Business Ethics 145(4), 771-780. https://doi.org/10.1007/s10551016-3186-7

Stuart, A. \& Peter, W., 2017, 'Navigating the study of executive leaders spirituality: Andre Delbecq's journey', Journal of Management Inquiry 26(2), 216-224. https://doi.org/10.1177/1056492616679734

Toro-Jaramillo, I.-D. \& Ramírez, J., 2017, 'La Gestión Empresarial desde un enfoque Humanista', Ponencia presentada en el Centro de Desarrollo Empresarial [From the exegesis of the Beatitudes to its Christian praxis Matthew 5, 3-10], Medellín, 16 de noviembre de 2017.

Tourish, D. \& Tourish, N., 2010, 'Spirituality at work, and its implications for leadership and followership: A post-structuralist perspective', Leadership 6(2), 207-224. https://doi.org/10.1177/1742715010363210

Vila, C., 2017, Ser cristiano hoy: Propuesta humanizadora en Mt 5, 3-10.

Vila, C., 2013, 'De la exégesis de las bienaventuranzas a su praxis cristiana Mateo 5 , 3-10' [From the exegesis of the Beatitudes to its Christian praxis Matthew 5, 3-10], Cuestiones Teológicas 40(93), 173-196.

Vilmante, K-V., 2014, 'Spirituality at work: Comparison analysis', Procedia-Social and Behavioral Sciences 150(15), 1205-1212. https://doi.org/10.1016/j.sbspro.2014. 09.136

Vine, W., 1999, Diccionario Expositivo de palabras del Antiguo y del Nuevo Testamento Exhaustivo [Expository Dictionary of Old and New Testament words Comprehensive], Caribe, Barranquilla.

Wahid, N.K.A. \& Mustamil, N.M., 2017, 'Ways to maximize the triple bottom line of the telecommunication industry in Malaysia The potentials of spiritual well-being through spiritual leadership', Journal of Organizational Change Management 30(2), 263-280. https://doi.org/10.1108/JOCM-07-2015-0105

Weinberg, F. \& Locander, W., 2014, 'Advancing workplace spiritual development: A dyadic mentoring approach', Leadership Quarterly 25(2), 391-408. https://doi. org/10.1016/j.leaqua.2013.10.009

Yazdani, N. \& Murad, H., 2014, 'Toward an ethical theory of organizing', Journal of Business Ethics 127(2), 399-417. https://doi.org/10.1007/s10551-014-2049-3 